\title{
Empirical Analysis of Interactions of Agricultural Sector and HIV/AIDS Pandemic in Africa
}

\section{Temidayo Gabriel Apata}

Department of Agricultural Economics and Extension Services, Joseph Ayo Babalola University, Ikeji-Aakeji, Nigeria. Email: dayoapata@yahoo.com

Received January $30^{\text {th }}, 2013$; revised March $2^{\text {nd }}, 2013$; accepted March $10^{\text {th }}, 2013$

Copyright (C) 2013 Temidayo Gabriel Apata. This is an open access article distributed under the Creative Commons Attribution License, which permits unrestricted use, distribution, and reproduction in any medium, provided the original work is properly cited.

\begin{abstract}
This study examines long run economic cost of HIV/AIDS on agriculture. Twenty-two African Countries were identified through purposive sampling. The sampling procedure helped to identify 1420 affected households. However, 1300 observations were found suitable for the subsequent analysis. Data were subjected to descriptive statistics and Overlapping Generation (OLG) model. The causes of high prevalence rates are the issue of poverty, fertility, myth and migration among others. Factors responsible for the classification of high HIV/AIDS prevalence rates were the patterns of spread of infectious disease that are closely associated with patterns of human mobility. For lower HIV/AIDS prevalence rate factors were low values of procreation and high values placed on morals. A positive correlation between HIV prevalence and GDP per capita was found. The study found out that there is a curvilinear relationship between the course of the HIV/AIDS epidemic and agricultural/economic growth in terms of human capita development.
\end{abstract}

Keywords: HIV/AIDS Prevalence Rates; Long-Run Economic Cost; Overlapping Generation (OLG) Model; Econometric Inference; Africa

\section{Introduction}

Investigation to know human being with HIV/AIDS by simply observing signs and symptoms has not helped. It is worthwhile to be aware of the fact that people with HIV infection may remain asymptomatic (show no symptoms) for quite a long time by feeling and looking healthy, therefore, you cannot tell who has the virus by mere looking at people. Studies have shown that you cannot know who has HIV except an HIV test is carried out through the following process: a small amount of blood is taken from patient, the result is given only to the person concerned and there will be counseling about the result whether positive or negative. The infections that often develop because HIV has weakened the system, which is known as opportunistic infections, including respiratory infections, such as tuberculosis: some form of unusual pneumonia or meningitis. Some people may also develop cancers, e.g. Karposi sarcoma, a cancer that often causes red skin lesions.

Studies have indicated that when a person becomes infected with HIV, some develop germs fighters, called antibodies, to fight off and destroy the virus that have invaded the body. It takes a little while for the body to produce measurable amount of antibodies after infection. For HIV this period is usually $2-12$ weeks, called the "Window period". This means that an HIV antibody test is taken during the window period, it will be negative, but the person is HIV infected and can transmit it to others. The clinical symptom of HIV infections appears to be increasingly complexed as indicated. It includes manifestations due to opportunistic diseases, as well as illness directly caused by HIV itself. These include acute phase; latency phase; persistent generalized lymphadenopathy; AIDS-related complex.

Facts from national economic statistics of most African countries revealed that the economies of these countries are predominantly agricultural and the agricultural sector is a major contributor to the country's Gross Domestic Product (GDP) [1]. These proofs indicated that this sector contributes about 80 per cent to the GDP annually and it provides employment for about 80 per cent of the population $[2,3]$. Studies have revealed that poverty prevalence at the homes of those who has taken agriculture as a source of livelihood with no other means of income [4-6]. An agricultural activity in most African countries depends on human labour and studies have shown that the degree of labour supply to agriculture is 
gradually reducing because of HIV/AIDS endemic [7]. With the increasing incidence and spread of HIV/AIDS, the epidemic is creating drastic changes in the supply of human labour, thus affecting agricultural labour supply and outputs.

Literature has shown that HIV/AIDS affects people in their productive age groups (15 - 49 years), resulting in a loss of agricultural labour [8-11]. In addition caregivers who have to give up working in the fields and farms in order to take care of the sick who will be deprived of labour for agricultural activities [12,13]. A projection made by World Bank in 1997 on adult's deaths due to infectious diseases in developing countries revealed that HIV/AIDS will have the highest rate of growth in death from infection, and by 2020, the death rate is expected to rise by $37.1 \%$ annually from the present $5 \%-7 \%$ [14].

Moreover, evidence from similar studies revealed that on average two person-years of labour are lost by the time of death in an AIDS-affected household in Africa [15,16]. Literature has also shown that HIV/AIDS pandemics are commonly found among productive age groups $[17,18]$. These studies noted that resulting effect of this is loss of agricultural labour not only from the people who die, but also from caregivers who have to give up working in the fields in order to take care of the sick. According to FAO global estimates, 25.5 million agricultural workers have died of AIDS since 1985 to 2006 and more than 16 million will die by 2020 [19]. Consequently, there is an urgent need for a study to capture the long run economic cost of this endemic on agricultural development.

Relatively little research has been done to capture the long run economic cost of HIV/AIDS on agriculture. To the knowledge of the researcher, similar studies like [20] that looked at this direction only looked at the impact of HIV/AIDS and agriculture, none of these studies captured the long run economic cost of this endemic. This study addresses this gap in the literature by examining the long run economic cost of HIV/AIDS on agriculture for effective locale specific agricultural policy information and directions.

\subsection{Problem Statement}

Majority of the population in the countries most affected by HIV/AIDS live in rural areas. In many African countries, farming and related occupations provide a livelihood for more than 70 per cent of the population [21]. Hence, it is to be expected that HIV/AIDS epidemic will cause serious damage to the agricultural sector. Evidence has shown that HIV/AIDS is no longer restricted to cities [22]. The disease is now spreading with alarming speed into rural areas and affects the farming population, especially people in their most productive years (ages 15 to 45). In addition, many HIV-infected urban dwellers re- turn to their village of origin when they fall ill. Rural households (particularly women) provide most of the care for AIDS patients. In addition, food, medical care costs and funeral expenses are primarily borne by rural families [23].

Recent data suggest that the HIV/AIDS epidemic is continuing to evolve. It is estimated that over 90 per cent of the close to 30 million people who are thought to have been infected worldwide with the virus since the start of the epidemic live in developing countries. With around 14 million HIV-infected adults and children as of late 1996, sub-Saharan Africa is the region hardest hit. This represents around 65 per cent of the world total. Of the 8 500 new infections that occur daily worldwide, 50 per cent are in Africa. It is estimated that around 5 million adults and 1.4 million children worldwide have already died since the start of the global epidemic [24].

To understand changes in incidence and prevalence within countries in Africa, detailed stratification of the prevalence rates into high, medium and low status can help identify particular patterns of spread and change within countries subgroups which may not emerge when only a general sample of the continent (Africa) is taken. Such stratification into classes will help to identify specific policy that can help to ameliorate the problems. In each country the details of the epidemic vary, having its own distinct origin, geographic patterns of dispersion and particular population subgroups affected. At present, reliable comprehensive statistics for HIV/AIDS infections do not exist; however, those that do exist are alarming. If the current epidemic trends continue through the end of this decade, it is estimated that between 30 and 40 million adults will have been infected with HIV by the year 2020 . Of these, about 60 per cent will be in sub-Saharan Africa $[25,26]$.

Thus, the challenge that the spread of HIV poses to the economy and agriculture in particular calls for urgent attention. There is a huge volume of literature on poverty and HIV/AIDS. However, studies explaining the economic long run cost of interactions between the HIV/AIDS and agricultural sector are almost non-existent. Empirical evidence regarding the examination of the long run economic cost of HIV/AIDS pandemic on agricultural sector is therefore justified. FAO provided an estimated and projected percentage of labour force for countries hit by HIV/AIDS. Evidence in this paper revealed that, in Namibia, the percentage of labour loss in 2000 is 3.0 while the estimated loss of labour in 2020 will be 26.0. However, the long run economic cost of this epidemic was not captured by this study [27].

Moreover, in Eastern and Southern Africa where HIV prevalence rates generally exceed 10 percent; AIDS mortality will produce population pyramids and by the year 2015, six countries in the region will be experiencing 
negative population growth rates: Botswana $(-2.1$ percent per year), Mozambique ( -0.2 percent), Lesotho $(-0.2$ percent), Swaziland ( -0.4 percent), and South Africa $(-1.4$ percent). By 2025, summing across these countries where HIV prevalence exceeds 20 percent, there will be roughly 20 million men in the working age years between 20 and 59 years with HIV/AIDS as opposed to 31.5 million if AIDS had not existed.

One of the ways this paper will go about it is to examine countries where HIV prevalence is low such as in Northern Africa, as this will help to give an insight on where this study can find its relevance. This is argued from the point that, firstly there is need to design agricultural policies and programme that can lower percentage of employment in the agricultural sector, secondly, introducing early maturity and yielding crops to reduce drudgery in agriculture and finally sensitization on the need to practise "safe sex" always.

Consequently, examining this interaction of HIV/AIDS and agriculture, the study assesses the long-run economic costs of HIV/AIDS on Agricultural sector for 22 African Countries. These countries were identified through databases and literature of HIV/AIDS and agricultural sector. Also, the study explores the potential implications of putting in place locally specific and effective agricultural policy that can reduce the pandemic of HIV/AIDS endemic. Due to the nature of the study where 22 countries were used, data requirements for this study are secondary. Secondary data were taken from US census bureau, 2008 and The World Fact Book, 2011. Secondary information helped to stratify the HIV/ADIS prevalence of the countries identified into high, medium and low rates respectively.

\subsection{Literature Review}

There is a growing literature that explores the relationships between HIV/AIDS pandemic and agriculture. This study reviewed literature on this line, looking at the effects of HIV/AIDS on household composition, labour allocation, and on agricultural production. Most research on HIV/AIDS has focused either on the household head or on the persons living with AIDS (PWLA) as the unit of analysis, but for studies of agricultural production, the household is generally considered to be the relevant unit of analysis [28]. In sub-Saharan Africa, households account for the majority of agricultural production. Agricultural production is the main source of self-employment, and the majority of households rely on household labour for agricultural production. Many authors stress that the effect of HIV/AIDS-related illness and mortality depends on which members are affected and on the demographic structure of the remaining household members [29]. The loss of a household member due to HIV/AIDS has led to widespread changes in household structures, including an increasing number of widows and widowers, increases in female or orphan-headed households, and the break-up of families [30].

Several case studies have documented the impacts of HIV/AIDS on agriculture, mostly on its impact on food security of affected households [31]. For example, a survey carried out in 1997 in Zimbabwe found out that agricultural output declined by nearly 50 per cent in the households affected by AIDS [32]. Similarly, RomeroDaza et al., in their study in Côte d'Ivoire found out that switching to food crops rather than cash crops (that demands huge labour) led to a drop in cash crops production by two thirds of previous levels [33].

A study conducted in Ethiopia showed reduction in agricultural labour time as a result of HIV/AIDS: the number of hours per week in agriculture fell from 33.6 hours in non-afflicted households to between 11 and 16 hours in afflicted households [33]. AIDS is expected to have a greater impact on agricultural labour supply in the future. According to estimates by FAO (2011), 12 countries (including 10 most affected African countries) that have recorded high prevalence of HIV/AIDS experienced labour force decrease that ranges between 10 to 26 per cent.

Past studies have indicated that HIV/AIDS has caused a decline in the supply of labour for food and livestock production [34]. The decline is caused by the illness and deaths of people living with AIDS and the time spent by household members in caring for sick relatives. In Tanzania, a study found that a woman whose husband was sick spent 45 per cent less time on agricultural tasks than a woman whose husband was healthy [35]. In Ethiopia an HIV/AIDS epidemic has caused shifts of production from cash crops to food crops in AIDS-affected households. The change has resulted in lower household incomes [36].

The discussion of the links between health and growth already provides many pointers to this connection. Taylor specifies a model of child mortality as an explanatory variable, and estimates that an HIV prevalence of 10 per cent initially reduces growth by 1.2 per cent [37]. Similarly, Dixon et al. and Barnett indicated that HIV/AIDS negatively affect economic growth through declining life expectancy [7,37]. Among recent studies, Hadju et al., find a negative (but very small) impact of reported [38] AIDS cases on growth. Zagheni reported a negative link between HIV/AIDS and HIV prevalence, and caution that it is not robust [39]. One striking aspect of the empirical literature on the impacts of HIV/AIDS is that it reduces life expectancy or mortality, while the evidence from direct approaches (adding HIV prevalence or mortality to growth regressions) is much weaker. 
From the foregoing it was clearly shown that HIV/ AIDS has caused serious havoc in agricultural sector and interventions are necessary to forestall HIV/AIDS pandemic expansion.

\section{Methodology}

\subsection{Area of Study}

Twenty-two African Countries were used as locale of study. These countries were identified through databases and literature of HIV/AIDS and agricultural sector [40, 41]. Information about these countries helped to classify the HIV/ADIS prevalence of the countries identified into high, medium and low rates respectively. These data presented here should be interpreted with caution, as some of the data are more than a little out-dated. However; more recent country-level data (applying somewhat different methodologies) for the eastern zone like Namibia, Lesotho, and Botswana are broadly consistent with the data presented in Table 1.

\subsection{Method of Data Collection}

Secondary data were used for this study and were obtained from UNAIDS website, Department of Medical Statistics and Epidemiology, University College Hospital
(UCH) Ibadan, Nigeria, US census bureau, 2008 and The World Fact Book, 2011. Information was also sourced from www.unaids.org, www.cbnrm.net, www.fhi.org, www. abcg.org, www.who.org, www.populationreports.org.

\subsection{Sampling Procedure}

Purposive sampling procedure was used in the first stage of sampling, where twenty-two countries in Africa as identified as HIV/AIDS ravaged countries were purposively selected in this first stage (Table 1). These countries are spread over four zones of the Northern Africa, the Eastern, the Southern and the West Africa. It was observed that the study areas are characterized by high, medium and low HIV/AIDS rates incidences respectively. The classification of the prevalence rates was adapted from secondary sources as below 3\% low rates, between 3\% $7 \%$ as medium and above $7 \%$ high prevalence rates respectively. It was observed the Southern zone has high prevalence rate (Table 2), Eastern zone has all the three characteristics; the West recorded medium rate prevalence while the Northern zone has low HIV/AIDS incidence respectively (Table 2 ). In the second stage, communities that were ravaged with HIV/AIDS incidences were purposively selected to represent the three cases in

Table 1. HIV prevalence in Africa and No. of people affected in agricultural industry.

\begin{tabular}{|c|c|c|c|c|c|c|}
\hline $\mathrm{S} / \mathrm{N}$ & Country & Population & $\begin{array}{c}\text { National adult HIV } \\
\text { prevalence } \\
15 \text { - } 49 \text { years \% }\end{array}$ & $\begin{array}{l}\text { No. of people } \\
\text { affected }\end{array}$ & $\begin{array}{l}\text { No. of people that derived } \\
\text { livelihood in agriculture and } \\
\text { in percentages }(\%)\end{array}$ & $\begin{array}{c}\text { No of people affected by } \\
\text { HIV and derived livelihood } \\
\text { in agriculture }\end{array}$ \\
\hline 1 & Nigeria & $140,003,562$ & 3.1 & $4,340,110$ & $105,002,672(75)$ & $3,255,083$ \\
\hline 2 & South Africa & $43,718,530$ & 18.1 & $5,700,000$ & 22,733,636 (52) & $4,114,788$ \\
\hline 3 & Ethiopia & $67,851,781$ & 2.3 & 980,000 & $42,407,363(62.5)$ & 675,369 \\
\hline 4 & Tanzania & $36,668,225$ & 6.2 & $1,400,000$ & $25,314,875$ (69) & $1,156,952$ \\
\hline 5 & Cote-Ivorie & $16,804,785$ & 3.9 & 655,387 & $11,427,254(68)$ & 445,663 \\
\hline 6 & Kenya & $32,021,856$ & 6.7 & $2,721,868$ & $23,375,955$ (73) & $1,986,956$ \\
\hline 7 & Egypt & $76,117,421$ & 2.2 & $1,674,583$ & $50,237,498(66)$ & $1,105,225$ \\
\hline 8 & Zimbabwe & $12,671,861$ & 15.3 & $1,305,202$ & 8,616,865 (68) & 887,537 \\
\hline 9 & Zambia & $10,462,436$ & 15.2 & $1,265,955$ & $6,800,583$ (65) & 822,871 \\
\hline 10 & Sudan & $39,148,162$ & 2.6 & $1,017,852$ & 27,795,192 (71) & 722,675 \\
\hline 11 & Morocco & $32,209,101$ & 2.3 & 740,809 & $19,325,460(60)$ & 444,486 \\
\hline 13 & Lesotho & $1,865,040$ & 23.2 & 395,388 & $951,704(51)$ & 200,697 \\
\hline 14 & Botswana & $1,561,973$ & 23.9 & 360,815 & 859,085 (55) & 198,449 \\
\hline 15 & Namibia & $1,954,033$ & 15.3 & 363,450 & $1,231,040(60)$ & 228,974 \\
\hline 16 & Swaziland & $1,169,241$ & 26.1 & 190,000 & $713,237(61)$ & 95,573 \\
\hline 17 & Malawi & $18,811,731$ & 11.9 & $2,407,901$ & $13,356,329(71)$ & $1,709,610$ \\
\hline 18 & Mozambique & $11,906,855$ & 12.5 & $1,333,568$ & 8,096,661 (68) & 906,826 \\
\hline 19 & Uganda & $26,404,543$ & 13.1 & 3,458,995 & $19,011,271(72)$ & $2,490,477$ \\
\hline 20 & Rwanda & 7,954,013 & 15.3 & $1,216,964$ & $5,885,970(74)$ & 900,553 \\
\hline 21 & Guinea & $7,775,065$ & 3.4 & 769,352 & $5,520,296(71)$ & 546,240 \\
\hline 22 & Togo & $5,285,501$ & 3.3 & 641,905 & $3,699,851(70)$ & 449,336 \\
\hline
\end{tabular}

Source: US census bureau, 2008, The World Fact Book, 2011, UNDP, 2012. Note: As the majority of people infected with HIV are unaware they have the virus, it is reasonable to expect that there may be significant cases of under-reporting and inaccuracies in certain listed statistics above. Sources may vary wildly between sources or between years as new or old information is discarded or acquired. Documented cases lists do not give an accurate description of the epidemic, but the study does attempt to quantify actual known cases, as well as documented cumulative impact. 
Table 2. List of identified African Countries grouped according to zone and HIV/AIDS prevalence rates.

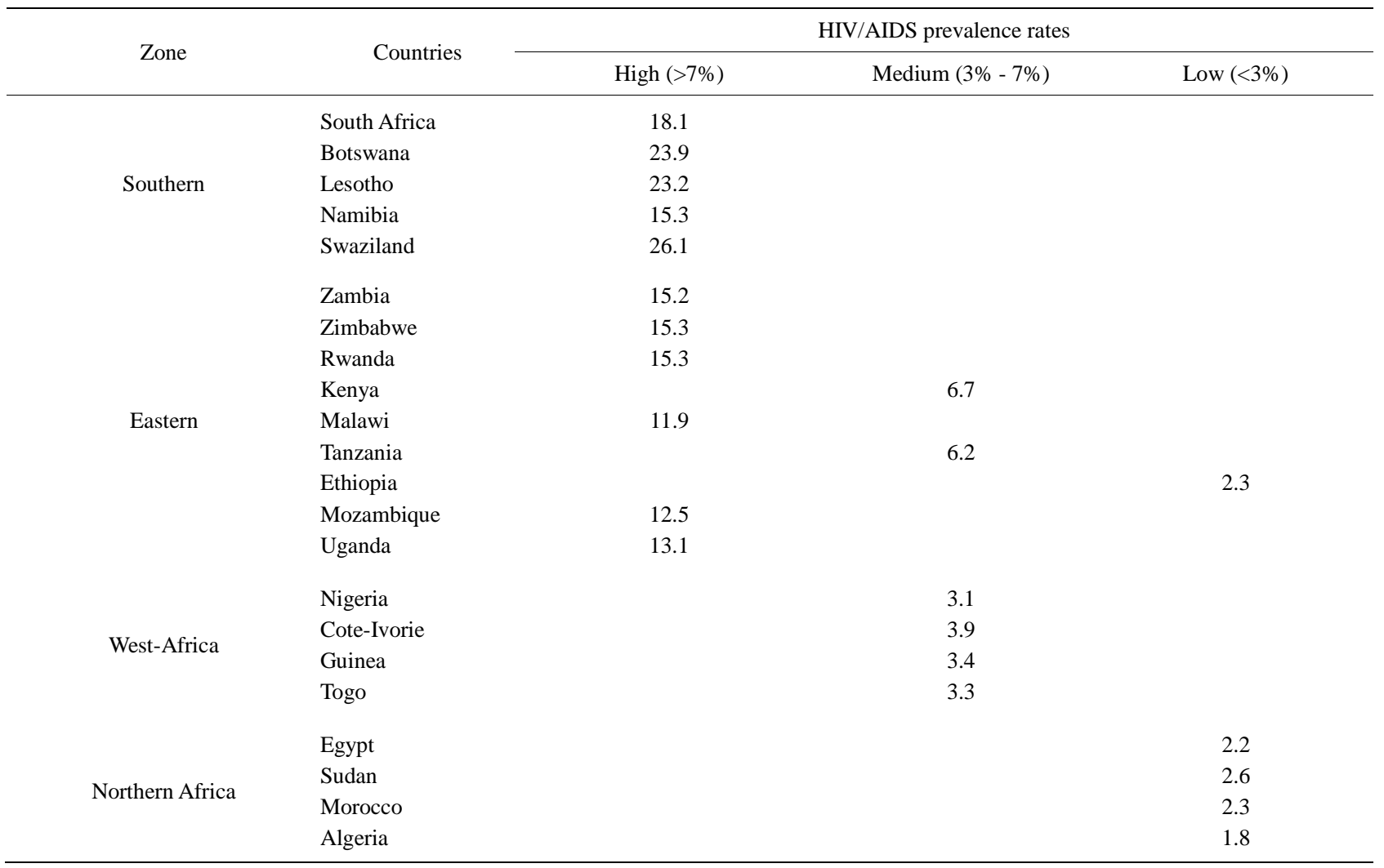

Source: Author's calculations based on the following sources; FAOSTAT, 2011, UNDP 2011.

all the zones (Table 2). Thus, 400 affected households were randomly picked in the Southern Zone, 520 in the Eastern zone, 280 households in the Northern zone and southwest, 220 households respectively for a total of 1420 affected households in the final stage of sampling. However, 1300 observations were found suitable for the subsequent analysis. Data were subjected to descriptive statistical and Overlapping Generation (OLG) model.

\section{Modelling}

\subsection{Overlapping Generation (OLG) Model}

To analyse the long-term economic effects of HIV/AIDS on Agricultural sector, some of the specific features of the relationship between health and economic growth must be treated in detail. In particular, there must be a link between the course of the epidemic and economic growth, in the form of feedbacks from premature mortality to education, the formation of human capital and output. For this purpose, the extension of the overlapping generations (OLG) model of Bell and Gersbach was adopted and modified to suit the purpose of the study. This model analyses the nexus of child labour, education and growth; investigate the causes of some existing level of premature adult mortality and its effects on economic growth [42].
The model specified that Parents have preferences over current consumption and the level of human capital attained by their children, making due allowances for early mortality in adulthood. The decision about how much to invest in education is influenced by premature adult mortality in two ways: first, the family's lifetime income depends on the adults' health status, and second, the expected pay-off depends on the level of premature mortality among children themselves when they attain adulthood. The outbreak of AIDS leads to an increase in such mortality, and if the prevalence of the disease becomes sufficiently high, there may be progressive collapse of human capital, productivity and economic growth.

The policy problem, therefore, is to avoid such a collapse. The instruments available for this purpose are 1) spending on measures to contain the disease and treat the infected; 2) aiding orphans, in the form of income-support or subsidies contingent on school attendance; and 3) taxes to finance the expenditure program. The central policy problem is to find the right balance among these interventions in order to ensure economic growth over the long run without excessive inequality. First, the very nature of the model demands that the available economic and demographic series be long and fairly reliable if there is to be a solid base for calibration. Second, inves- 
tigate African countries that have experienced substantial growth over years and the resultant effect of HIV/AIDS pandemics. Third, the epidemic has progressed rapidly in these selected African countries, from a prevalence rate among the population aged 15 to 49 of about one per cent in 1990 to over 20-percent a decade later [43].

\subsection{The Model Specification}

The study extends the OLG-model of Bell and Gersbach by introducing premature mortality among adults [44]. There are two periods of life, childhood and adulthood, whereby the course of adulthood runs as follows. On becoming adults, individuals immediately form families and have their own children. When the children are very young, they can neither work nor attend school. Since the only form of investment is education, the family's full income is wholly consumed in this phase. Only when this phase is over do the adults learn whether they will die prematurely, and so leave their children as half- or full orphans. Early in each generation of adults, therefore, all nuclear families are sorted into one of the following four categories: Both parents survive into old age; the father dies prematurely; the mother dies prematurely and both parents die prematurely.

These states are denoted by $s_{t} S_{t}:=\{1,2,3,4\}$. The probability that a family formed at the start of period $t$ lands in category $s_{t}$ is denoted by $\pi_{t}\left(s_{t}\right)$. The population is assumed to be large enough and the fractions of all families in that state after all premature adult death have occurred. We turn to the formation of human capital. Consider a family at the start of period $t$. Let $\lambda_{t}^{f}$ and $\lambda_{t}^{m}$ denote, respectively, the father's and mother's endowments of human capital, and let $\mathrm{A}_{t}\left(s_{t}\right)$ denote their total human capital when the family is revealed to be in state $s_{t}$. Then,

$$
\Delta_{c}(1) \lambda_{t} 3 A 4 \lambda_{t}^{m} 0_{c}()=\lambda_{t}^{m}{ }_{c}()=\lambda_{t}^{f}{ }_{t}()=
$$

An additional source of heterogeneity is ruled out in advance:

Assumption 1. There is assortative mating: $\lambda_{t}^{f}=\lambda_{t}^{m} V_{t}$. Hence, (1) specializes to

$$
\Lambda 1\left(\Lambda \mathbb { Z } \Lambda 3 \mathrm { A } _ { \mathrm { b } } 4 _ { c } \left(0={ }_{c}()=\lambda_{t} \quad{ }_{t t}()=\right.\right.
$$

Human capital is assumed to be formed by a process of child rearing combined with formal education in the following way. In the course of rearing their children, parents give them a certain capacity to build human capital for adulthood, a capacity which is itself increasing in the parents' own human capital. This gift will be of little use, however, unless it is complemented by at least some formal education, in the course of which the basic skills of reading, writing and calculating are learned. Ex- pressed formally, the human capital attained by each of the children on reaching adulthood is assumed to be given by

$$
\left\{\begin{array}{l}
Z_{(s t)} f_{(e t)} \Lambda_{t(s t)}+\mathbb{\Lambda}, 2, t 3= \\
\Lambda_{t+1}=\zeta 4 s t=
\end{array}\right.
$$

Beginning with the upper branch of (3), the term $\mathrm{z}_{t}\left(\mathrm{~s}_{t}\right)$ represents the strength with which capacity is transmitted across generations. It is plausible that the father's and mother's contributions to this process are not perfect substitutes, in which case, $2 z(1)>\operatorname{Max}[z(2), z(3)]$ and $z(2)$ may not be equal to $z(3)$. For simplicity, however, we introduce.

Assumption 2. $z(2)=z(3) \geq z(1) \geq z(2) / 2=z(3) / 2$

$Z(1)=z(2)=z(3)$ holds when parents are perfect complements and $2 z(1)=z(2)=z(3)$ when they are perfect substitutes. Assumptions 1 and 2 allow the upper branch of (3) to be rewritten as

$$
\lambda_{t}+1=(3-s t) z_{(s t)} f_{(e i)} \lambda_{t}+1, s t=1,2
$$

Both types of single-parent families are being identical in this respect. The function $f(0)$ may be thought of as representing the educational technology-translating time spent on education into learning.

Assumption 3 is a continuous, strictly increasing and differentiable function on $[0,1]$, with $f(0)=0$.

\subsection{The Household's Behavior}

It is assumed that all allocated decisions lie in the parents' hands, as long as they are alive. We rule out any bequests at death, so that the whole of current income, as given by (5), is consumed. Concerning the allocation of consumption within the family let the husband and wife enjoy equality as partners, and let each child obtain a fraction $\beta \in(0,1)$ of an adult's consumption if at least one adult survives. Full orphans $\left(s_{t}=4\right)$ do not attend school, and consume what they produce as child laborers.

From (2), the budget sets of single-mother and singlefather households with the same endowments of human capital and the same number of children are identical. In the absence of any taxes or subsidies, the household's budget line may therefore be written as

$$
\begin{aligned}
& {[(3-s t)+n t \beta] c t(s t)+\alpha \operatorname{nt} \gamma \mathrm{et}(s t) } \\
= & \alpha[(3-s t) \lambda t+\mathrm{nt} \gamma], \quad s t=1,2,3
\end{aligned}
$$

where $c_{t}\left(s_{t}\right)$ is the level of each adult's consumption.

The expression on the LHS represents the costs of consumption and the opportunity costs of the children's schooling. The expression on the RHS is the family's socalled full income in state' $s_{t}=1,2,3$, whereby assumption 1 ensures that states 2 and 3 are identical where the budget set is concerned. Observe that single-parent households not only have lower levels of full income than their 
otherwise identical two-parent counterparts, but they also face a higher relative price of education, defined as $\left.\alpha \mathrm{n}_{t} \gamma /\left(3-s_{t}\right)+\mathrm{n}_{t} \boldsymbol{\beta}\right]$.

Parents are assumed to have preferences over their own current consumption and the human capital attained by their children in adulthood, taking into account the fact that an investment in a child's education will be wholly wasted if that child dies prematurely in adulthood. Let mothers and fathers have identically preferences, and for two-parent households, let there be no "joint" aspect to the consumption of the pair $\left(c_{t}(1), e_{t}(1)\right)$ : each surviving adult derives (expected) utility from the pair so chosen, and these utilities are then added up within the family. In effect, whereas $c_{t}(1)$ is a private good, the human capital of the children in adulthood is a public good within the marriage. Since all the children attain $\lambda t+1$, the only form of uncertainty is that surrounding the number who will not die prematurely as adults, which is denoted by $a_{t}+1$. Let preferences by separable, with representation.

$$
\begin{aligned}
& E U t(s t)=(3-s t)[\mathrm{u}(c t(s t))+E t a+1 v(\lambda t+1)], \\
& s t=1,2
\end{aligned}
$$

where the contribution $v\left(\lambda_{t}+1\right)$ counts only when death does not come early, $E_{t}$ is the expectation operator and $E_{t} a_{t}+1$ is the expected number of children surviving into old age. The sub-utility functions $\mathrm{u}(\cdot \lambda)$ and $\mathrm{v}(\lambda)$ are assumed to be increasing, continuous, concave and twicedifferentiable. Denoting by $\pi_{t}+1\left(s_{t}+1\right)$ the parents subjective probability that a child will find itself in state $s_{t}+1$ in period $t+1$, so that: $\sum_{s t+1=1}^{4} \pi_{t+1}(s t+)=$, and recalling Assumption 1 and that all children are treated identically, we obtain

$$
\operatorname{Etat}+1 v(\lambda t+1)=\mathrm{n} t \kappa t+1 v(\lambda t+1)
$$

where

$$
K_{t+1} \equiv\left[\begin{array}{lll}
1 \pi 1 & \text { att } & (t)-2 t+()] /
\end{array}\right.
$$

We are interested in the question: how does the outbreak of the disease affect the subsequent development of the society? Children who are left as unsupported orphans $\left(s_{o}=4\right)$ fall at once into the poverty trap. Assumption 7 also implies that $e^{0}(2 \xi, 1)=0 \mathrm{Vt}$ : even if both parents survive but have been orphans in childhood, they cannot afford to send their children to school. In the absence of support, therefore, all orphans fall into the poverty trap, and their succeeding lineage remains there. In order to discover what happens to the rest, we introduce the critical value function $\lambda_{\left(s, k_{t}\right)}^{*}$ for $s \in\{1,2,3\}, \mathrm{n}_{t}+1=$ $\mathrm{n}_{t}, \mathrm{~V} t$ and $\kappa_{t}=\kappa$, Vt defined by:

$$
\lambda_{(s, k)}^{*}=z_{(s)} f e^{0}\left(\Lambda s^{*}(s)(\mathrm{s}) k\right) 1 * \quad+
$$

In order to estimate the long-run economic cost of HIV/AIDS on agriculture the OLG model was used. The variables used borrow from the works of Bell et al., $[44,45]$. The long-run economic cost of HIV/AIDS on agricultural sector is therefore conceptualize through the model of OLG as

$$
\mathrm{V} t=\mathrm{f}\left(X_{1}, X_{2}, X_{3}, \cdots, X_{15}\right)
$$

The estimating equation is represented as:

$$
V_{t}=\beta_{0}+\beta_{1} X_{1}+\beta_{2} X_{2}+\beta_{3} X_{3}+\cdots \beta_{15} X_{15}+\mu
$$

where

$$
\begin{aligned}
\mathrm{V} t= & \text { Long-run economic costs of HIV/AIDS } \\
& \text { on agricultural sector. }
\end{aligned}
$$

$\beta_{0}=$ Constant term

$\mathrm{X}_{1}-\mathrm{X}_{15}=$ Independent variables.

$\mathrm{U}=$ Error term assumed to have normal distribution with zero mean,

and constant variance i.e. $\mathrm{U} \sim \mathrm{N}\left(0 \sigma^{2}\right)$ and $\mathrm{E}\left(\mathrm{U}_{\mathrm{i}}, \mathrm{U}_{\mathrm{j}}\right)=0$ ij.

The following variables are hypothesized as having significant influence on the economic cost of HIV/AIDS: Household size $\left(\mathrm{X}_{1}\right)$, level of education $\left(\mathrm{X}_{2}\right)$, age $\left(\mathrm{X}_{3}\right)$, information on HIV/AIDS, protective and preventive measures $\left(\mathrm{X}_{4}\right)$, hired labour $\left(\mathrm{X}_{5}\right)$, inputs $\left(\mathrm{X}_{6}\right)$, expenses on food $\left(\mathrm{X}_{7}\right)$, opportunity cost of own labour $\left(\mathrm{X}_{8}\right)$, cropping/fishing income $\left(\mathrm{X}_{9}\right)$, number of non-farm rural activities $\left(\mathrm{X}_{10}\right)$, market facilities $\left(\mathrm{X}_{11}\right)$, access to extension facilities $\left(\mathrm{X}_{12}\right)$ cost of credit facilities $\left(\mathrm{X}_{13}\right)$, cost of health services $\left(\mathrm{X}_{14}\right)$ and frequency of visit to hospital for care or medications $\left(\mathrm{X}_{15}\right)$. The selections of these variables were based on economic theory and suggestions of previous/similar studies. The OLS technique was used to estimate the model.

\section{Results}

Table 3 depicted the causes and effects of the 3 scenarios the study adopted. They are high, medium and low prevalence rates respectively. Analysis from Table 3 revealed that the causes of high prevalence rates are the issue of poverty. For instance without jobs women have no money, thus they have to look for other means of supporting their family. Many of them turn or are forced to exchange sex for money as a last resort. Past studies indicated that although poor women are usually aware of AIDS, they have no other alternative for earning money in order to survive. Thus, what is seen as means of survival (sleeping with multiple partners) is, in reality, a means of an untimely death because of the high risk of contracting HIV/AIDS $[1,47,48]$.

Moreover, in Africa fertility is seen as demonstrating the masculinity and manliness of men and because procreation is highly valued in African society, both men and women are refusing to use condoms. Even though condoms are successful in preventing the spread of AIDS, 
Table 3. HIV/AIDS prevalence rates, causes and effects on economic growth.

\begin{tabular}{|c|c|c|c|}
\hline Prevalence rate & Causes & Effect & Implications on economic growth \\
\hline High & $\begin{array}{l}\text { 1. Poverty } \\
\text { 2. High values of procreation } \\
\text { 3. Myths } \\
\text { 4. Poor Health } \\
\text { 5. Long Latency Period } \\
\text { 6. Regional Migration } \\
\text { 7. Poverty-driven that to promote risky } \\
\text { sexual behaviour } \\
\text { 8. Socio-cultural and behavioural factors } \\
\text { 9. High population density } \\
\text { 10. Stigma on Condom use } \\
\text { 11. limitedinformation on HIV/AIDS }\end{array}$ & $\begin{array}{l}\text { Disease continues to wipe out the } \\
\text { poor and the rich, and the young } \\
\text { and the old, leaving behind } \\
\text { destroyed families and few skilled } \\
\text { workers which only add to Africa's } \\
\text { social instability. }\end{array}$ & $\begin{array}{l}\text { High unemployment. } \\
\text { unwanted pregnancies } \\
\text { population growth. } \\
\text { changes in age structure } \\
\text { (active age population). }\end{array}$ \\
\hline Medium & $\begin{array}{l}\text { Sex between men } \\
\text { is officially forbidden, } \\
\text { nutrition and disease synergism } \\
\text { cultural and regional variables } \\
\text { culture, religion and governance. } \\
\text { Regional migration }\end{array}$ & $\begin{array}{l}\text { Rising rural epidemic. } \\
\text { Labour out migration } \\
\text { prime age adult infection } \\
\text { and mortality. }\end{array}$ & $\begin{array}{l}\text { High inequality in wealth income } \\
\text { distribution } \\
\text { Global economic slowdown }\end{array}$ \\
\hline Low & $\begin{array}{l}\text { Low values of procreation } \\
\text { culture and religion. } \\
\text { High values placed on morals. } \\
\text { Sexual behaviour. } \\
\text { Limitation to women's right and status }\end{array}$ & $\begin{array}{l}\text { Limited rate of partner change. } \\
\text { Controlled sexual practices. }\end{array}$ & $\begin{array}{l}\text { Fairly wealth income distribution. } \\
\text { Sound social and economic policy. } \\
\text { Smaller population. }\end{array}$ \\
\hline
\end{tabular}

Source: Author's extrapolation from several literature reviewed and past studies.

they also prevent reproduction. Thus, many individuals are willing to risk contracting AIDS and have unprotected sex.

A myth as another factor influences the spread of HIV/ AIDS in many ways. One strong belief held by a number of Africans is that the West wants to control the population growth of Africa, and what the West is trying to do is convincing Africans to use condoms. The West is encouraging African nations to use condoms as protection against AIDS, but many Africans believe that this is just a ploy to curb reproduction rates. In addition, many Christians in Africa believe that God is using AIDS as a weapon to punish sinners. Since AIDS is often associated with promiscuity, many followers believe that God will protect the innocent spouse from contracting AIDS, but use AIDS to punish the spouse that was involved in sexual practices outside of her/his marriage [45,49,50].

The study argued that the medium rates, prevalence and patterns of spread of infectious disease are closely associated with patterns of human mobility in this zone $[28,51]$. Thus the continuous movement of people is an underlying factor in the spread of HIV/AIDS. Massive migration of young, unmarried adults from presumably “conservative” rural environments to more sexually permissive African cities in recent years has been regarded as partly responsible for the much higher infection levels observed in urban than in rural areas [46,52].

For the low rate of HIV/AIDS prevalence, the analysis indicated that low values of procreation, culture and religion, high values placed on morals, sexual behaviour and limitation to women's right and status were major characteristics found in this group. In addition, limited rate of partner change, controlled sexual practises, fairly wealth income distribution, sound social and economic policy and smaller population density were identified as determinants.

\section{HIV Prevalence, GDP per Capita and Long-Run Economic Cost}

The analysis of the possible effect of HIV/AIDS and economic transformation in the context of development were associated with high degrees of inequality $[1,53]$. Analysis on Table 4 includes some of the most advanced economies in eastern zone. The apparent correlation between high degrees of inequality and high HIV prevalence is sometimes interpreted causally. For example, Piot et al. discuss links between poor governance, inequality, and HIV prevalence, pointing at the "clear pattern of association between income inequality and HIV prevalence across countries in Eastern Africa [54,55]. The study found out that "inequality is a stronger predictor of HIV prevalence than poor governance,” and suggest "that economic growth that is not pro-poor could lead to greater income inequality".

Table 4 presents the correlation between HIV prevalence, the Gini coefficient, and GDP per capita.

Clearly, GDP per capita is much more closely correlated with HIV prevalence than the Gini coefficient (which turns just insignificant at the 10 per cent level). It 
is further evidence that the coefficients for both the Gini coefficient and GDP per capita are not robust and essentially fall to zero. Thus, apart from the fact that HIV prevalence is high in this zone (which also happen to feature relatively high levels of GDP per capita and income inequality), the cross-country evidence does not support the hypothesis that HIV prevalence is related to inequality or GDP per capita. However, inequality is nevertheless relevant for our analysis of the long-run economic cost of HIV/AIDS.

The analysis presented on Table 5 suggests that HIV/ AIDS did have a large impact on the growth or level of GDP or GDP per capita. Therefore, it becomes imperative to examine factors that may contribute to this finding.

\section{Discussion}

A major finding of this paper is that poverty, religion and migration variables have direct effect on the level of HIV/AIDS prevalence in Africa. On the other hand, healthcare, economic development education and information on condom use do not seem to have a direct effect on the prevalent rates of HIV infection. Caution need to be exercise here when interpreting the foregoing statement.However higher levels of education and economic development are, indeed, very essential in controlling and preventing an epidemic like AIDS. A plausible explanation for the lack of significance for the foregoing variables is that in eastern zone (high prevalence region) particularly in the southern region, the epidemic seems to have caught both governments and their respective societies unprepared.

The religion variable show direct and insignificant results. A plausible reason why Christianity and Islam are not significant (when not interacted with their respective region counterpart) is that African regions, unlike the dominancy of Christianity in the south and Islam in the north, possess plural religious and cultural values systems. More specifically, religious and cultural diversity in eastern, central, and western seem to lead to the overall decreased impact of Christianity and Islam on the continent's epidemic. The Healthcare variable is insignificant, while education and economic development shows significant level. Migration variable show some statistically significant effects on the epidemic on high and medium district while low region show no statistically significant effects. A plausible explanation for this may be due to the fact that several of the countries in these regions have a greater mix of policy of restriction on immigrants.

Table 4. HIV prevalence, GDP per capita and long-run economic cost.

\begin{tabular}{cccc}
\hline & Dependent variable, HIV prevalence, 2010 & & Medium \\
\hline & High & $-4.4-(1.3)$ & $3.2^{* * *}(2.1)$ \\
\hline Constant & $-12.3^{* * *}(2.4)$ & $0.21 \quad(1.52)$ & $0.006 \quad(0.03)$ \\
Gini coefficient & $0.38^{* *}(3.1)$ & $0.003^{*}(3.1)$ & $-0.0027-(0.28)$ \\
GDP per Capita & $0.0058^{* *}(3.8)$ & 0.48 & 0.41 \\
$\mathrm{R}^{2}$ & 0.57 & & \\
\hline
\end{tabular}

Source: Author's estimates based on data from FAOSTAT, IMF (2009), UNDP (2008), and UNAID (2008). Note: ${ }^{*}$ Indicates $10 \%$, ${ }^{* *} 5 \%$ and ${ }^{* * *} 1 \%$ One, significant level respectively.

Table 5. OLS estimates of the main explanatory variables of the dependent variable: adult HIV/AIDS prevalence (2009).

\begin{tabular}{lccc}
\hline \multicolumn{1}{c}{ Variables } & High & Medium & Low \\
\hline Intercept & $2.58^{* *}(0.57)$ & $2.23^{* *}(0.49)$ & $1.87^{* *}(0.31)$ \\
Poverty & $1.14^{* *}(0.58)$ & $0.09^{* *}(0.47)$ & $0.007(0.21)$ \\
Religion & $0.03^{* *}(0.15)$ & $0.018^{*}(0.12)$ & $0.003(0.003)$ \\
Healthcare & $-0.07(0.06)$ & $0.03(0.07)$ & $0.01(0.06)$ \\
Migration & $0.05(0.14)$ & $0.09(0.13)$ & $0.03(0.07)$ \\
Economic development & $-1.26(058)$ & $-0.91(0.47)$ & $-0.87(0.43)$ \\
Education & $-0.01(0.01)$ & $-0.004(0.004)$ & $-0.012(0.09)$ \\
Information on condom use (Yes = 1 and 0 otherwise) & $-1.13^{* *}(0.56)$ & $-0.73(0.53)$ & $0.45^{* *}(0.17)$ \\
$\mathrm{R}^{2}$ & 0.58 & 0.47 & 0.42 \\
\hline
\end{tabular}

Source: multiple regression computer results. ${ }^{* *} \mathrm{p}<0.05$; two-tailed test; Bs are unstandardized betas; standard errors in parentheses. 
In addition, the positive sign and the consistent significance of the HIV/AIDS data indicate that the epidemic has been spreading on the African continent since 1997; when effective action is not taken by governments and their respective societies. On the issue of religion, Christianity in the Eastern zone has statistically significant effects on the HIV infection. However, it is not being a Christian per se that seems to foster the spread of the epidemic. For instance, the predominantly Christian in Western European and North American societies have one of the lowest HIV infections in the world. The clue to this puzzle is found when we compare southern Africa with northern Africa. The northern African societies are predominantly Muslim, and they have strict religious and legal prohibitions to pre- and extra marital sex. As a result, the average HIV infection rate in northern Africa is as low as the HIV infection rates in Western European and North American societies.

The foregoing cases support the assumption that religion is a good proxy of cultural variations on the African continent. In southern Africa, however, although Christianity prohibits pre- and extra marital sex, there is no legal enforcement to such practices. The institution of commercial sex, which facilitates the spread of AIDS, is also prevalent in southern Africa. Thus, pre- and extra marital sexual relations are not uncommon in this region [56]. Therefore, it is perhaps the less prohibitive nature of the social and cultural norms of southern Africans that facilitate the spread of the epidemic in this region. In other words, the Christianity variable serves only as a proxy for the cultural values and norms of southern Africa. Indeed, the religion (Christian) variable has provides some credence to the foregoing statement. In other words, in the absence of social and legal enforcements, Islam will not likely curtail the spread of AIDS, and
Christianity by itself does not seem to foster the spread of AIDS. Put differently, the dominant value systems of northern and southern Africa seem to affect the minority value systems of these regions. For instance, the curtailment of prostitution in northern Africa may have benefited the Christians of that region from contracting AIDS, and the less prohibitive social and cultural environment of southern Africa may have denied an extra advantage to the Muslims of this region in preventing AIDS. In sum, religion in the African context seems to be only a proxy of the general cultural phenomena in the region.

\section{Over-Lapping Generation (OLG) Model}

Analysis of the results of long-run economic costs of HIV/AIDS on Agricultural sectors was presented on Table 6. The results revealed the $R^{2}$ of $74 \%$ and the Standard Error of 0.02514 indicated a good fit for the estimated equation. Results from the long-run economic costs of HIV/AIDS equation indicate that agricultural sector was affected negatively and significantly by age $\left(\mathrm{X}_{3}\right)$ information on HIV/AIDS, prevention and protective measures $\left(\mathrm{X}_{6}\right)$, and access to credit $\left(\mathrm{X}_{13}\right)$. Thus, the higher the age, information on HIV/AIDS, prevention and protective measures and access to credit used to raise production variables the lower the spread of HIV/AIDS (Table 6). The results also indicated that education $\left(\mathrm{X}_{2}\right)$, income $\left(\mathrm{X}_{6}\right)$, number of non-farm rural activities $\left(\mathrm{X}_{10}\right)$, access to extension services $\left(\mathrm{X}_{12}\right)$ Cost of health services $\left(\mathrm{X}_{14}\right)$, and frequency of visit to hospital for care or medications $\left(\mathrm{X}_{15}\right)$. All have significant positive effects on long-run economic cost (Table 6). The results reveal that income $\left(\mathrm{X}_{6}\right)$ was the most significant factor influencing the spread of HIV/AIDS. This means that poor households struggle for additional income to meet household needs including engaging in commercial/casual sex work.

Table 6. Ordinary least square for OLG regression analysis.

\begin{tabular}{lcc}
\hline \multicolumn{1}{c}{ Variable } & Estimate & t-value \\
\hline Household size $\left(\mathrm{X}_{1}\right)$, & $-2.1481 \mathrm{E}-04$ & -0.1345 \\
level of education $\left(\mathrm{X}_{2}\right)$, & 0.7251 & $2.4131^{*}$ \\
Age $\left(\mathrm{X}_{3}\right)$, & $-7.9135 \mathrm{E}-03$ & $-2.2652^{*}$ \\
Information on HIV/AIDS, prevention & $-4.5821 \mathrm{E}-03$ & $-3.3546^{* * *}$ \\
and protective measures $\left(\mathrm{X}_{4}\right)$, & $-4.5482 \mathrm{E}-07$ & -1.0523 \\
Hired labour $\left(\mathrm{X}_{5}\right)$, & $1.7245 \mathrm{E}-08$ & $3.2543^{* *}$ \\
Inputs $\left(\mathrm{X}_{6}\right)$, & $-2.4431 \mathrm{E}-07$ & -0.2988 \\
Expenses on food $\left(\mathrm{X}_{7}\right)$, & $2.335 \mathrm{E}-06$ & 0.7654 \\
Opportunity cost of own labour $\left(\mathrm{X}_{8}\right)$, & $-4.4652 \mathrm{E}-09$ & -0.6635 \\
Income $\left(\mathrm{X}_{9}\right)$, & $5.5134 \mathrm{E}-07$ & $2.3852^{*}$ \\
Number of non-farm rural activities $\left(\mathrm{X}_{10}\right)$, & 0.5192 & 0.3107 \\
Market facilities $\left(\mathrm{X}_{11}\right)$, & 0.6453 & $2.4127^{*}$ \\
Access to extension facilities $\left(\mathrm{X}_{12}\right)$, & 0.00859 & $-3.0048^{* *}$ \\
Cost of credit facilities $\left(\mathrm{X}_{13}\right)$, & 0.00203 & $3.1162^{* *}$ \\
Cost of health services $\left(\mathrm{X}_{14}\right)$, & & $2.5643^{*}$ \\
Frequency of visit to hospital & 0.0185 & \\
for care/medication $\left(\mathrm{X}_{15}\right)$, & & \\
\hline
\end{tabular}

Source: Results from the regression analysis. HIV prevalence rate as the dependent variable. Diagnosic statistics: ${ }^{* * *}$ Significant at $\mathrm{p}<0.001,{ }^{* *}$ Significant at $\mathrm{p}<$ 0.005 , " Significant at $\mathrm{p}<0.01$; Multiple R $=0.8253$, R Square $=0.7691$, Adjusted R Square $=0.7432$, Standard Error $=0.02514$. Constant $=-0.0103$. 
Similarly, educations, NFRA, access to extension services and access to market facilities have positive significant effect on long-run economic cost of HIV/AIDS (Table 6). Increases in these variables will lead to increase long-run economic cost of HIV/AIDS. As households realize that they can make more money from other sources than farming they may gradually shift away from farming livelihood. The implication is that interest in farming will be gradually declining and can lead to scarcity of agricultural products or food shortages, threatening food security and legalize commercial sex work as livelihood in the area of study.

The results suggest that there is a curvilinear relationship between the course of the HIV/AIDS epidemic and agricultural/economic growth in terms of human capita development. The findings from this study has clearly shown there is the need for policies to promote economic growth and poverty alleviation Macro models from this study has projected that AIDS has affected GDP growth of countries where there is HIV/AIDS prevalence.

\section{Conclusions}

The finding of this study revealed that there is a positive correlation between HIV prevalence, the Gini coefficient, and GDP per capita. GDP per capita is much more closely correlated with HIV prevalence than the Gini coefficient, thus establishing the long-run economic cost. The crosscountry evidence supports the hypothesis that HIV prevalence is related to inequality or GDP per capita. The study found out that there is a curvilinear relationship between the course of the HIV/AIDS epidemic and agricultural/economic growth in terms of human capita development. The implication is that as HIV/AIDS prevalence continuing to affect human labour, reducing the effectiveness of labour for agricultural production, agricultural outputs will witness reduction. Determining factors influencing HIV/AIDS prevalence rates were poverty, myths, and migration among others. Poverty was found as the most significant factor. Majority of poor households engaged primarily in agriculture. Households that therefore engaged in non-farm activities were better off. The estimates suggest that as households realize that they can make more money from other sources than farming they may be gradually shifting away from farming. Thus interest in farming will be gradually declining and can lead to scarcity of agricultural products or food shortages, threatening food security and legalize commercial sex work as option. Econometric inference from this study suggests that a small impact of HIV/AIDS on the macroeconomic level can coincide with increases in poverty and inequality.

The study discovered that religion and value system practised were the determinants of lower rates experienced in the Northern zone. The zone has a very strict religious and legal prohibition to pre- and extra marital sex and high cultural value systems. The curtailment of prostitution in Northern Africa may have benefited the Christians of that region from contracting AIDS, and the less prohibitive social and cultural environment of Southern Africa may have denied an extra advantage to the Muslims of this region in preventing AIDS. This policy from Northern zone can be used in other zones to curtail the spread of HIV/AIDS prevalence.

The need for practical, sustainable HIV programs in developing countries, where the disease burden is greatest and urgent. Of the estimated 37.9 million people with HIV in 2010, 22.5 million were from sub-Saharan Africa, where the adult prevalence rate is $5.0 \%$. Economically, the cost spents on treating AIDS victims could provide essential amenities in no AIDS scenarios. Studies in $\mathrm{Zu}-$ luland in South Africa revealed that the cost of the drug zidovudine (AZT) for 1 HIV/AIDS person is more than that of 1 community health centre for a year.

Reviewed of past studies and lesson learnt from countries where HIV/AIDS prevalence was low (e.g. Cuba) suggest that for effective HIV/AIDS controlled, there is the need for continuous programme to remind the young people and adults alike of the value of not being promiscuous, of staying faithful to one partner and of not engaging in risky behaviour. In addition, measures that will stop all behaviour that causes the spread of AIDS, like Ancient traditions, sexual taboos and laws making iresponsible behaviour illegal should be taken and backed it up.

There should be studies of people who are immune to AIDS. For example, according to US News and World Report (January 29, 2001: p. 40) "Some people with Eastern European roots have a gene that confers resistance to AIDS." Governments and Pharmaceuticals companies in Africa and worldwide should conduct studies to see whether cures can be created from these "anti AIDS genes." After all, it is the resistance of some Africans to malaria that has helped to create anti-malaria vaccines. Finally, there is the need to review laws (both customary and written) and their implementation to protect the safety of people living with HIV and AIDS and their families, like free access to antiretroviral drugs among others.

Agriculture is at the heart of the lives of rural people and it can be made into a powerful tool to reduce the potential of HIV infection, as well as contribute to mitigating the effects of infection. Therefore, agricultural policy should focus on improving the productivity of smallscaled farmers. The HIV/AIDS pandemic has demonstrated that a more balanced approach is necessary. This is a challenge to agriculturist policy makers; the price of failure is just too high when the lives and welfare of over 
1.5 billion rural people are at stage, not to mention the economic dimensions involved.

\section{REFERENCES}

[1] H. Stockl, L. Heise and C. Watts, “Moving beyond Single Issue Priority Setting: Associations between Gender Inequality and Violence and Both HIV Infection and Poor Maternal Health in Malawi,” Geneva, UNAIDS, 2012. http://www.unaids.org/en/media/unaids/contentassets/docu ments/unaidsrfp/2012/rfp-2012-14/MultivariateAnalysis_ Semi-Final_Draft2.pdf

[2] P. Collier and J. W. Gunning, "Why Has Africa Grown So Slowly?” The Journal of Economic Perspectives, Vol. 13, No. 3, 1999, pp. 13-21.

[3] P. C. Ferreira, S. Pesso and R. Dos Santos, "The Impact of AIDS on Income and Human Capital,” Economic Inquiry, Vol. 49, No. 4, 2011, pp. 1104-1116. doi:10.1111/j.1465-7295.2010.00273.x

[4] S. Chen and M. Ravallion, "How Are the World's Poorest Fared since the Early 1980s?” World Bank Policy Research Working Paper, No. 3341, 2004, p. 24.

[5] G. Owuor, M. Ngigi, A. Ouma and E. Birachi, "Determinants of Rural Poverty in Africa: The Case of Smallholder Farmers in Kenya,” Journal of Applied Sciences, Vol. 7, No. 17, 2007, pp. 2539-2543. doi:10.3923/jas.2007.2539.2543

[6] T. G. Apata, J. Omidiji and T. Adegbola, "Youth and HIV/AIDS in Nigeria," Paper Presented at the Conference of Inform Package Training on Data Sieving and Transfer for TDF (Clinical Drug Trials) of HIV/AIDS Prevention and Safety Project, Tema, 25-28 April 2004.

[7] C. Dawn, I. Parker, H. Kathryn, T. Jacobsen and M. K. Komwa, "A Qualitative Study of the Impact of HIV/ AIDS on Agricultural Households in South-Eastern Uganda," International Journal of Environmental Research and Public Health, Vol. 6, 2009, pp. 2113-2138.

[8] K. Annan, "A Call to Action against HIV/AIDS, with Five Clear Objectives: Being an Address Presented to the United Nations to the World Health Assembly," Geneva, 2001.

[9] Population Reports, "Youth and HIV/AIDS; Can We Avoid the Catastrophe?” Adolescents and Youth, Vol. 29, No. 3, 2001, pp. 1-35.

[10] J. Verheijen, “Complexities of the 'Transactional Sex' Model: Non-Providing Men, Self-Providing Women, and HIV Risk in Rural Malawi,” Annals of Anthropological Practice, Vol. 35, No. 1, 2011, pp. 116-131. doi:10.1111/j.2153-9588.2011.01070.x

[11] S. Harman, "Governing Health Risk by Buying Behaviour,” Political Studies, Vol. 59, No. 4, 2011, pp. 867883.

[12] M. Haacker, "Impact of and Responses to HIV/AIDS: Public Policy Challenges,” In: E. Lule, R. Seifman and A. C. David, Eds., The Changing HIV/AIDS Landscape, Washington DC, World Bank, 2009.

[13] D. W. Sellen and C. Hadley, "Food Insecurity and Maternal-to-Child Transmission of HIV/AIDS in Sub-Saha- ran Africa,” Annals of Anthropological Practice, Vol. 35, No. 1, 2011, pp. 28-49. doi:10.1111/j.2153-9588.2011.01065.x

[14] World Bank, "Intensifying Action against HIC/AIDS in Africa,” Responding to a Development Crisis, 1997.

[15] J. Guerney, "Agriculture and HIV/AIDS in Africa: Can Agricultural Sector Make a Difference,” FAO, 2001.

[16] World Bank, “Cash Payments Can Reduce HIV/Sexually Transmitted Infections in Africa-New Bank Studies,” 2011.

[17] D. Ross and B. Ferguson, "HIV/AIDS in Young People: A Systematic Review of the Evidence from Developing Countries,” WHO, Geneva, 2006.

[18] S. Harman, "The Dual Feminisation of HIV/AIDS," Globalisations, Vol. 8, No. 2, 2011, pp. 213-218. doi:10.1080/14747731.2010.493023

[19] Food and Agriculture Organization (FAO), "Global AIDS Estimates,” 2006.

[20] G. Aymone and C. Ringler, "Mapping South African Farming Sector Vulnerability to Climate Change,” A Subnational Assessment, IFPRI Discussion Paper 00885, 2009.

[21] L. Gulaid and K. Kiragu, "Promising Practices in Community Engagement. Global Plan towards the Elimination of New HIV Infections among Children by 2015 and Keeping Their Mothers Alive," CCABA/UNICEF/UNAIDS/Global Fund/RIATT Road to Washington Meeting, Addis Ababa, Ethiopia, Toronto, 2-3 December 2011. http://www.ccaba.org/road-to-washington-addis-ababa

[22] M. Muñoz, "Matching Social Support to Individual Needs: A Community-Based Intervention to Improve HIV Treatment Adherence in a Resource-Poor Setting," AIDS and Behavior, Vol. 15, No. 7, 2011, pp. 1454-1464. doi:10.1007/s10461-010-9697-9

[23] T. Barnett and A. Whiteside, "Poverty and HIV: Impact, Coping and Mitigation Policy,” In: G. A. Cornia, Ed., Public Policy and Child Well-Being UNICEF Innocenti Research Centre, Vol. 25, 2007, pp. 209-244.

[24] UNAIDS, “World AIDS Day Report,” 2012. http://www.unaids.org/en/media/unaids/contentassets/doc uments/unaidspublication/2011/JC2216_WorldAIDSday_ report_2011_en.pdf

[25] J. Seeley, S. Dercon and T. Barnett, "The Effects of HIV/ AIDS on Rural Communities in East Africa: A Twenty Year Perspective," Tropical Medicine and International Health, Vol. 15, No. 3, 2010, pp. 329-335. doi:10.1111/j.1365-3156.2009.02458.x

[26] R. Hajdu, N. Ansell, E. Robson, L. Van-blerk and L. Chipeta, "Income-Generating Activities for Young People in Southern Africa: Exploring AIDS and Other Constraints,” The Geographical Journal, Vol. 177, No. 3, 2011, pp. 251-263. doi:10.1111/j.1475-4959.2010.00381.x

[27] FAO, "HIV/AIDS and Agriculture: Impacts and Responses," Case Studies from Namibia, Uganda and Zambia, FAO, Rome, 2003.

[28] A. Chapoto and T. S. Jayne, "Impact of AIDS-Related Mortality on Farm Household Welfare in Zambia," Economic Development and Cultural Change, Vol. 56, No. 2, 2008, pp.327-373. doi:10.1086/522894 
[29] A. David and C. Carmen, "Exploring the Links between HIV/AIDS, Social Capital and Development,” Journal of International Development, Vol. 22, No. 7, 2010, pp. 941961. doi:10.1002/jid.1707

[30] B. Taylor, D. Bukenya, P. Asten, D. Ago, A. Pain and J. Seeley, "Review: The Impact of HIV on Agricultural Livelihoods in Southern Uganda and the Challenges of Attribution," Tropical Medicine and International Health, Vol. 16, No. 3, 2011, pp. 324-333. doi:10.1111/j.1365-3156.2010.02703.x

[31] P. H. Thangata, P. E. Hildebrand and F. Kwesiga, "Predicted Impact of HIV/AIDS on Improved Fallow Adoption and Rural Household Food Security in Malawi,” Sustainable Development, Vol. 15, No. 4, 2007, pp. 205-215. doi:10.1002/sd.323

[32] C. O. Kwaramba, "The Socio-Economic Impact of HIV/ AIDS on Communal Agricultural Production Systems in Zimbabwe," Zimbabwe Farmer's Union and Friederich Ebert Stiffung, Harare, 1997.

[33] N. Romero-Daza, D. A. Himmelgreen, A. Charlotte and D. Turkon, "Dealing with the Global Food Crisis in Local Settings: Nonintensive Agriculture in Lesotho, Southern Africa,” In: D. Himmelgreen, Ed., The Global Food Crisis: New Insights into an Age-Old Problem, NAPA Bulletin, Vol. 32, 2009, pp. 23-41.

[34] R. Slater and S. Wiggins, "Responding to HIV/AIDS in Agriculture and Related Activities Natural Resource," Perspectives, Vol. 98, No. 3, 2005, pp. 345-353.

[35] T. S. Jayne, M. Villarreal, P. Pingali and G. Hemrich, "HIV/AIDS and the Agricultural Sector: Implications for Policy in Eastern and Southern Africa," Journal of Agricultural Development, Vol. 2, No. 2, 2005, pp. 158-181.

[36] J. Seeley, J. Amurwon and S. Foster, "The Longitudinal Picture: What Does It Reveal?” In: A. Niehof, G. Rugalema and S. Gillespie, Eds., HIV/AIDS in Sub-Saharan Africa: Diverse Trajectories and Impacts, Earthscan, London, 2010.

[37] T. Barnett, “The Effects of HIV/AIDS on Farming Systems and Rural Livelihood in Uganda, Tanzania and Zambia,” Norwich, 2006.

[38] E. Zagheni, “The Impact of the HIV/AIDS Epidemic on Kinship Resources for Orphans in Zimbabwe,” Population and Development Review, Vol. 37, No. 4, 2011, pp. 761-783. doi:10.1111/j.1728-4457.2011.00456.x

[39] US Census Bureau, "The AIDS Pandemic in the 21st Century,” Report for 14th International Conference on AIDS, July 2008, Barcelona.

[40] UNAIDS Global AIDS Estimates, "Economic Development and Cultural Change,” 2011.

[41] C. S. Bell, C. Devarajan and H. Gersbach, "Long Run Economic Cost of HIV/AIDS,” Theory and Application to South Africa, 2003. www.developmentgateway.org

[42] C. Bledsoe, “The Politics of AIDS, Condoms, and Heterosexual Relations in Africa: Recent Evidence from the Local Print Media,” Durban, 2011.
[43] C. Bell and H. Gersbach, "Child Labour and the Education of a Society,” Alfred Weber Institute, University of Heidelberg, Germany, 2002.

[44] D. Bloom, D. Canning and J. Sevilla, "The Effect of Health on Economic Growth, Theory and Evidence,” NBER, Working Paper, No. 8587, 2001.

[45] F. Booysen, "HIV/AIDS, Poverty and Risky Sexual Behaviour in South Africa," African Journal of AIDS Research, Vol. 3, No. 1, 2004, pp. 57-67.

[46] M. Brockerhoff and A. E. Biddlecom, "Migration, Sexual Behavior and the Risk of HIV in Kenya," International Migration Review, Vol. 33, No. 4, 1999, pp. 833-856. doi: $10.2307 / 2547354$

[47] C. Grootaert, “The Determinants of Poverty in Cote d'Ivorie in the 1980s," Journal of African Economies, Vol. 6, No. 2, 1997, pp. 169-196.

doi:10.1093/oxfordjournals.jae.a020925

[48] P. H. Herath and H. Takeya, "Factors Determining Intercropping by Rubber Small Holders in Sri-Lanka: A Logit Analysis,” Agricultural Economics, Vol. 29, No. 2, 2003, pp. 159-168. doi:10.1111/j.1574-0862.2003.tb00154.x

[49] T. S. Jayne, M. Villarreal, P. Pingali and G. Hemrich, "Interaction between the Agricultural Sector and the HIV/ AIDS Pandemic: Implications for Agricultural Policy," Michigan State University, International Development Paper No.25, 2004.

[50] J. M. Kanyamurwa and G. T. Ampek, “Gender differentiation in Community Responses to AIDS in Rural Uganda,” AIDS Care, Vol. 19, Suppl. 1, 2007, pp. S64-S72. doi:10.1080/09540120601114683

[51] C. Miller, D. Bangsberg, D. Tuller, J. Senkungu, A., Kawuma, E. Frongillo and S. Weiser, "Food Insecurity and Sexual Risk in an HIV Endemic Community in Uganda," AIDS and Behaviour, Vol. 23, No. 4, 2010, pp. 219-227.

[52] J. Mukiza-Gapere and J. P. Ntozi, "Impact of AIDS on the Family and Mortality in Uganda," Health Transit Review, Vol. 5, 1995, pp. 191-200.

[53] T. R. Müller, "AIDS Mitigation through AgricultureBased Interventions in Rural Contexts: Junior Farmer Field and Life Schools and Future Livelihoods in Central Mozambique,” Singapore Journal of Tropical Geography, Vol. 31, No. 3, 2010, pp. 330-342. doi:10.1111/j.1467-9493.2010.00411.x

[54] P. Piot, R. Greener and S. Russell, "Squaring the Circle: AIDS, Poverty, and Human Development,” Public Library of Science Medicine, Vol. 4, No. 10, 2007, pp. 2331.

[55] C. Tsafack, "What Drives HIV/AIDS Epidemic in SubSaharan Africa," Working Paper, CERDI-CNRS, Université d’Auvergne, Auvergne, 2008

[56] V. Mishra, "A Study of the Association of HIV Infection, Religion and Wealth in Sub-Saharan Africa,” DHS Working Papers, Vol. 31, 2007, pp. 67-73. 